\title{
Profiling Genome-Wide DNA Methylation Patterns in Human Aortic and Mitral Valves
}

\author{
Sarah Halawa ${ }^{1,2}$, Najma Latif ${ }^{3,4}$, Yuan-Tsan Tseng ${ }^{3,4}$, Ayman M. Ibrahim ${ }^{1,5}$, Adrian H. Chester ${ }^{3,4}$, \\ Ahmed Moustafa ${ }^{2,6}$, Yasmine Aguib ${ }^{1,4}$ and Magdi Yacoub ${ }^{1,4 *}$ \\ $1 \quad$ Aswan Heart Centre, MYF, Egypt \\ 2 Biotechnology Graduate Program, American University in Cairo, New Cairo, Egypt \\ $3 \quad$ Magdi Yacoub Institute, Heart Science Centre, Harefield, UK \\ $4 \quad$ NHLI, Imperial College London, UK \\ 5 Zoology Department, Faculty of Science, Cairo University, 12613, Egypt \\ 6 Department of Biology, American University in Cairo, New Cairo, Egypt \\ * Authors to whom correspondence should be addressed
}

Short Running Title: Epigenetics of Heart Valves

\begin{abstract}
Cardiac valves exhibit highly complex structures and specialized functions that include dynamic interactions between cells, extracellular matrix (ECM) and their hemodynamic environment. Valvular gene expression is tightly regulated by a variety of mechanisms including epigenetic factors such as histone modifications, RNA-based mechanisms and DNA methylation. To date, methylation fingerprints of nondiseased human aortic and mitral valves have not been studied. In this work we analyzed the differential methylation profiles of 12 non-diseased aortic and mitral valve tissue samples (in matched pairs). Analysis of methylation data (reduced representation bisulfite sequencing (RRBS)) of 1601 promoters genome-wide revealed 584 differentially methylated (DM) promoters, of which 13 were reported in endothelial mesenchymal trans-differentiation (EMT), 37 in aortic and mitral valve disease and 7 in ECM remodeling. Both functional classification as well as network analysis showed that the genes associated with the DM promoters were enriched for WNT-, Cadherin-, Endothelin-, PDGF- and VEGF- signaling implicated in valvular physiology and pathophysiology. Additional enrichment was detected for TGFB-, NOTCH- and Integrin- signaling involved in EMT as well as ECM remodeling. This data provides the first insight into differential regulation of human aortic and mitral valve tissue and identifies candidate genes linked to DM promoters. Our work will improve the understanding of valve biology, valve tissue engineering approaches and contributes to the identification of relevant drug targets.
\end{abstract}

Keywords: epigenetics; heart valves; methylation; next generation sequencing (NGS); extracellular matrix (ECM); endothelial mesenchymal trans-differentiation (EMT); reduced representation bisulfite sequencing (RRBS); networks; promoters 
It is made available under a CC-BY-NC-ND 4.0 International license .

\section{Introduction}

Heart valves perform a range of sophisticated functions that ensure unidirectional blood flow during systole, prevent backflow during diastole, enhance coronary blood flow and maintain left ventricular as well as myocardial function [1]. These functions are sustained throughout the human's lifetime and require tight regulation of the valve cells and extracellular matrix (ECM), which continuously interact together enabling the valves to actively adapt to their complex hemodynamic and biomechanical environments $[1,2]$.

Valves have a unique trilamellar structure. This structure is formed through complex developmental processes starting with the generation of primordial cardiac cushions via endothelial mesenchymal transdifferentiation (EMT) [3]. Remodeling events that include cell differentiation, apoptosis, and ECM remodeling transform these cushions into valve leaflets [3]. Ultimately, the mature valves are composed of a valve endothelial cell (VEC) layer covering a central layered ECM, which comprises collagen, elastin, glycosaminoglycans and is populated by valve interstitial cells (VICs) [4]. The specific diversity and nature of the cells and ECM in each valve-type requires a distinct set of genes to be expressed, which is achieved via molecular regulation by genetic and epigenetic factors [5,6].

Epigenetics refers to heritable phenotype changes that do not involve changes in the DNA sequence itself and includes mechanisms such as histone modifications, RNA-based mechanisms and DNA methylation [7]. DNA methylation is a process by which a methyl group is added to the 5' carbon of cytosine, which alters the structure of the DNA molecule thus allowing differential regulation of gene expression either through obstructing transcription factor (TF) binding or through the recruitment of methyl-binding proteins, which bind complexes responsible for chromatin remodeling [8]. This process is heritable as well as tissue-specific and plays a major role in various physiological processes linked to cardiogenesis such as cardiomyocyte development, maturation and cardiac regeneration [9,10]. Aberrant changes in methylation profiles are associated with cardiovascular diseases (CVDs) such as ventricular septal defects, tetralogy of Fallot, atherosclerosis as well as other CVDs that lead to end-stage heart failure [11-14].

So far, few studies have addressed how DNA methylation affects valvular disease processes. These studies investigated DNA methylation mechanisms that can transform VICs of stenotic aortic valves into leukotriene-producing immune-like cells via targeted promoter methylation measurement of 5lipoxygenase (5-LO) [15], and those that lead to the disruption of both the organization of the ECM and the communication between the cells and the ECM in bicuspid aortic valve (BAV) by investigating miR-29 expression level utilizing qRT-PCR [16]. Other studies focused on uncovering associations between methylation changes and the development of rheumatic heart valve disease using ELISA [17], and on detecting the genome-wide DNA methylation landscape underpinning BAV and aortic dissection (AD) via methylation array [18].

To date, DNA methylation in human non-diseased mitral and aortic valves have not been reported. Understanding the unique DNA methylation patterns of non-diseased valves and the methylation differences between different types of human valves is crucial to understanding their biology and susceptibility to disease.

In this study, we investigated the differential methylation fingerprints of 12 human non-diseased aortic and mitral valve samples (in matched pairs) by the assessment of their methylation profiles generated via reduced representation bisulfite sequencing (RRBS). We assessed genes, whose promoters were significantly differentially methylated (DM) on a genome-wide level, and grouped those genes according to their molecular functions, biological processes, protein classes, and pathways. To gain a systems-level understanding of the patterns of methylation of aortic and mitral valve tissue we performed a network 
analysis, followed by a functional enrichment analysis on the constructed networks to identify significantly DM Gene Ontology (GO) terms and pathways characteristic of these valves. This work provides an initial insight into differential methylation profiles of non-diseased human aortic and mitral valve tissue, and shows the importance of a deep understanding of the tissue and cell-specific mechanisms in the nondiseased status.

\section{Materials and Methods}

\subsection{Ethics statement and study cohort/samples}

This study was approved by the Royal Brompton hospital ethics review board / Brompton and Harefield trust ethics committee (REC approval 10/H0724/18) and is abiding by all the standards of the Declaration of Helsinki. Written informed consent was obtained from the donors prior to their inclusion in the study. Twelve non-diseased valves free from calcification (6 aortic and 6 mitral valves; 10 males: 2 females; age range 42 - 64 years, mean age 52.2 years, SD 9.9682) were used in this study. After applying inclusion/exclusion criteria three of the twelve valves were excluded from the downstream analysis (Figure S1). The non-diseased valves were obtained from unused valves of healthy donor hearts, who died of noncardiac diseases (Table 1). History, macroscopic, and microscopic evaluation were additionally performed to make sure that the donor hearts chosen are free from cardiovascular and valvular complications. The exclusion criteria of donor hearts were previously described in [19].

Table 1. Cohort demographic and clinical characteristics.

\begin{tabular}{llll}
\hline Donor No. & Gender & Age & Cause of Death \\
\hline 1. & Male & 44 & $\begin{array}{l}\text { Transplant } \\
\text { recipient }\end{array}$ \\
2. & Male & 57 & $\begin{array}{l}\text { Intracerebral } \\
\text { hemorrhage }\end{array}$ \\
3. & Male & 42 & $\begin{array}{l}\text { Intracranial } \\
\text { thrombosis }\end{array}$ \\
4. & Male & 44 & $\begin{array}{l}\text { Transplant } \\
\text { recipient }\end{array}$ \\
5. & Male & 62 & $\begin{array}{l}\text { Intracerebral } \\
\text { hemorrhage }\end{array}$ \\
& & & $\begin{array}{l}\text { Intracerebral } \\
\text { hemorrhage }\end{array}$ \\
6. & Female & 64 & \\
\hline
\end{tabular}

\subsection{Tissue Sampling and DNA Extraction}

Aortic and mitral valves from donor hearts were provided by the Royal Brompton Valve biobank. The ischemic time for fresh tissue harvest was set to not exceed $24 \mathrm{~h}$. The aortic and mitral valve leaflets were excised and separately deendothelialized using collagenase II for 10 minutes at $37{ }^{\circ} \mathrm{C}$. The leaflets were then washed using PBS, snap frozen and stored in $-80^{\circ} \mathrm{C}$ for DNA extraction. DNA was isolated from 
It is made available under a CC-BY-NC-ND 4.0 International license .

deendothelialized tissue using the FitAmp ${ }^{\mathrm{TM}}$ Blood and Cultured Cell DNA Extraction Kit (Epigentek, NY, USA, catalog \#: P-1018) and was subsequently eluted in TE buffer in a total volume of $40 \mu 1$. DNA was finally quantified and quality controlled via fluorescence.

\subsection{Bisulfite Conversion, Library Preparation and Sequencing}

For each sample, $300 \mathrm{ng}$ of DNA was digested for 2 hours with the MSP1 enzyme (20U/sample at $\left.37^{\circ} \mathrm{C}\right)$ followed by 2 hours with Taq $\alpha \mathrm{I}\left(20 \mathrm{U} /\right.$ sample at $\left.65^{\circ} \mathrm{C}\right)$. Digested, CGI enriched DNA fragments less than $300 \mathrm{bps}$ in length, were selected for and subsequently collected for bisulfite treatment. Bisulfite treatment was performed using the Methylamp DNA Bisulfite Conversion Kit (Epigentek, NY, USA, catalog \#: P-1001). Bisulfite conversion efficiency of the bisulfite-treated DNA was determined by RTPCR using two pairs of primers against bisulfite-converted DNA (b-actin) and against unconverted DNA (GAPDH), for the same bisulfite-treated DNA samples. Conversion was deemed successful, if more than $99 \%$ of the DNA were converted (Epigentek, NY, USA).

For library preparation, first DNA end polishing and adaptor ligation was performed. This was followed by library amplification using indexed primers and library purification. The final purified library was eluted in $12 \mu \mathrm{l}$ of water. Assessment of library quality was done via bioanalyzer and KAPA library quantification (Roche, CA, USA). Finally, $10 \mathrm{nM}$ of sample libraries were subjected to single-end enhanced RRBS on Illumina HiSeq 2500.

\subsection{Data Quality Control (QC) and Processing}

A summary of the bioinformatics analysis workflow can be found in Figure 1. First, raw reads were subjected to QC using FastQC version 0.10.1 [20]. Trim Galore version 0.3.7 was then used to remove low quality reads, adapters as well as RRBS-related residues that are artificially added during the end-repair step [21]. Trimmed reads were then mapped to the UCSC Homo sapiens genome sequence (version hg19) using Bismark version 0.13.0 [22]. To permit only up to one mismatch per seed region, the option "-n 1" was set for Bowtie version 1.0.0 utilized by Bismark [23]. Samtools version 0.1.19-96b5f2294a, was utilized to sort the SAM file storing bisulfite alignment and methylation calling data produced by Bismark and to remove duplicate reads that result from PCR amplification [24]. Methylation information was extracted from Bismark's sorted and filtered mapping results at base resolution using Bismark's methylation extraction software [22]. The subsequent analysis was performed in the CpG context. The $\mathrm{R}$ package methylKit version 0.9.2 was used for further analysis of the Bismark methylation extraction reports [25]. Samples that generated a minimum of 60 million reads (Figure S1) were included in the analysis and processed methylKit. Methylation information found in the aforementioned extraction reports was summarized by methylKit over RefSeq promoters, defined as regions located $1 \mathrm{~kb}$ before or after a transcription start site [26]. Coverage for each promoter was calculated as the sum of the methylated and unmethylated cytosines. Percentage of methylation for each promoter was calculated as the number of methylated cytosines divided by the coverage multiplied by 100 . The promoters were subsequently filtered based on coverage (minimal 5 and maximal 99.9 percentile) and merged for comparative analysis with only those promoters that are covered in all replicates being considered. Additional QC steps can be found in the Supplementary Materials Online (Figure S2, Figure S3). RRBS data was deposited in EMBL-EBI's European Genome-phenome Archive (EGA) and is accessible through EGA's accession number EGAD00001006303. 
medRxiv preprint doi: https://doi.org/10.1101/2020.09.10.20190546; this version posted September 11, 2020. The copyright holder for this preprint (which was not certified by peer review) is the author/funder, who has granted medRxiv a license to display the preprint in perpetuity.

It is made available under a CC-BY-NC-ND 4.0 International license .

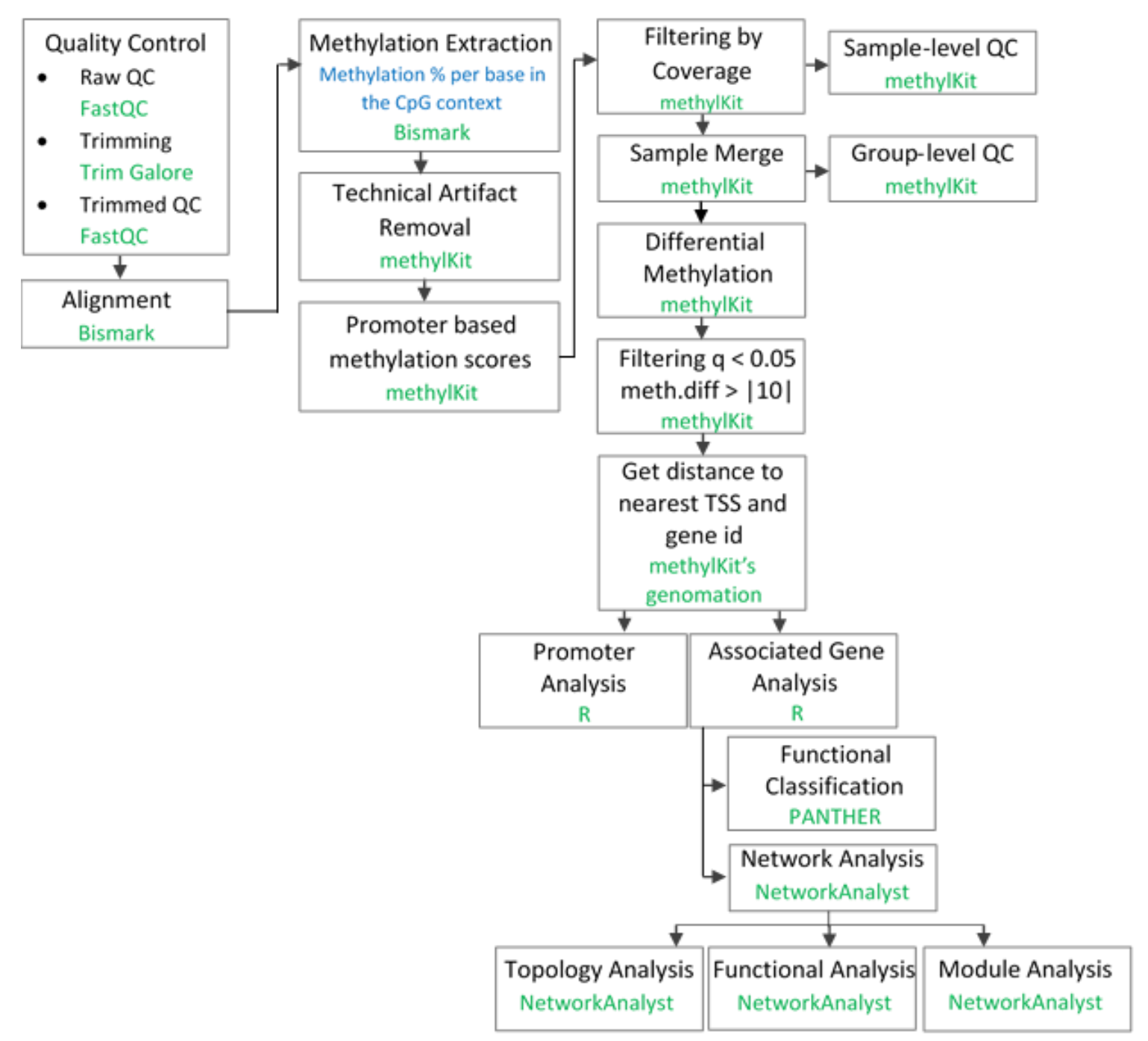

Figure 1. Summary of the data analysis workflow.

\subsection{Differentially Methylated Region (DMR) Analysis}

The difference in the methylation level of a promoter between aortic and mitral tissue was calculated as the difference between the weighted average of the percent methylation values of all mitral tissue samples and the weighted average of the percent methylation values of all aortic tissue samples at this promoter. A positive methylation difference (hypermethylation) indicated increased methylation in the promoter associated with mitral compared to aortic tissue. The significance of this difference was evaluated by methylKit using logistic regression [25]. To correct for multiple hypothesis testing, the sliding linear model (SLIM) method was used by methylKit [25]. DM promoters were finally filtered with the cut-off chosen as a methylation difference that is larger than $10 \%$ and a q-value that is less than 0.05 . Annotation of DMRs with genic features, primarily promoters, was carried out by methylKit using the genomation package [25]. 


\subsection{Pathway Enrichment Analysis}

The Protein Analysis Through Evolutionary Relationships (PANTHER) classification system was utilized to categorize genes whose promoters were found to be DM according to their molecular functions, biological processes, protein classes, pathways and cellular components [27].

\subsection{Construction of Protein-Protein Interaction (PPI) Networks}

Genes associated with DM promoters were used as seed genes to construct PPI networks using NetworkAnalyst [28]. The International Molecular Exchange (IMEx) Interactome database, which contains literature-curated comprehensive data from InnateDB, was used by NetworkAnalyst for the generation of the generic network [28]. For network construction, methylation difference values of alternative promoters of the same seed gene were replaced by their average before proceeding to network construction [28]. The resulting network was trimmed to the minimum to encompass only nodes that connect the original seed genes. Functional enrichment analysis of all seed genes was performed using NetworkAnalyst's Function Explorer using GO, KEGG and Reactome databases. Enrichment p-values were computed based on the hypergeometric test utilized by the Function Explorer [28]. NetworkAnalyst's Module Explorer, was used to identify smaller significantly densely connected subnetworks using the Walktrap algorithm [28]. Visualization of PANTHER, KEGG and Reactome pathway terms was performed using the GOplot R package [29].

\section{Results}

3.1. Aortic and mitral valves show different methylation signatures in 584 promoters

DMR analysis identified 584 significantly DM promoters, of which 305 showed increased methylation in mitral and 279 in aortic valve tissue (Figure 2, Figure S4, Table S1). The gene Repulsive Guidance Molecule A (RGMA) was associated with the most significantly DM promoter followed by TBC1 Domain Family Member 32 (TBC1D32), B-Cell Lymphoma 3 (BCL3) and the long non-coding RNA RP11-1149O23.3 among others (Figure 2, Table S1). 


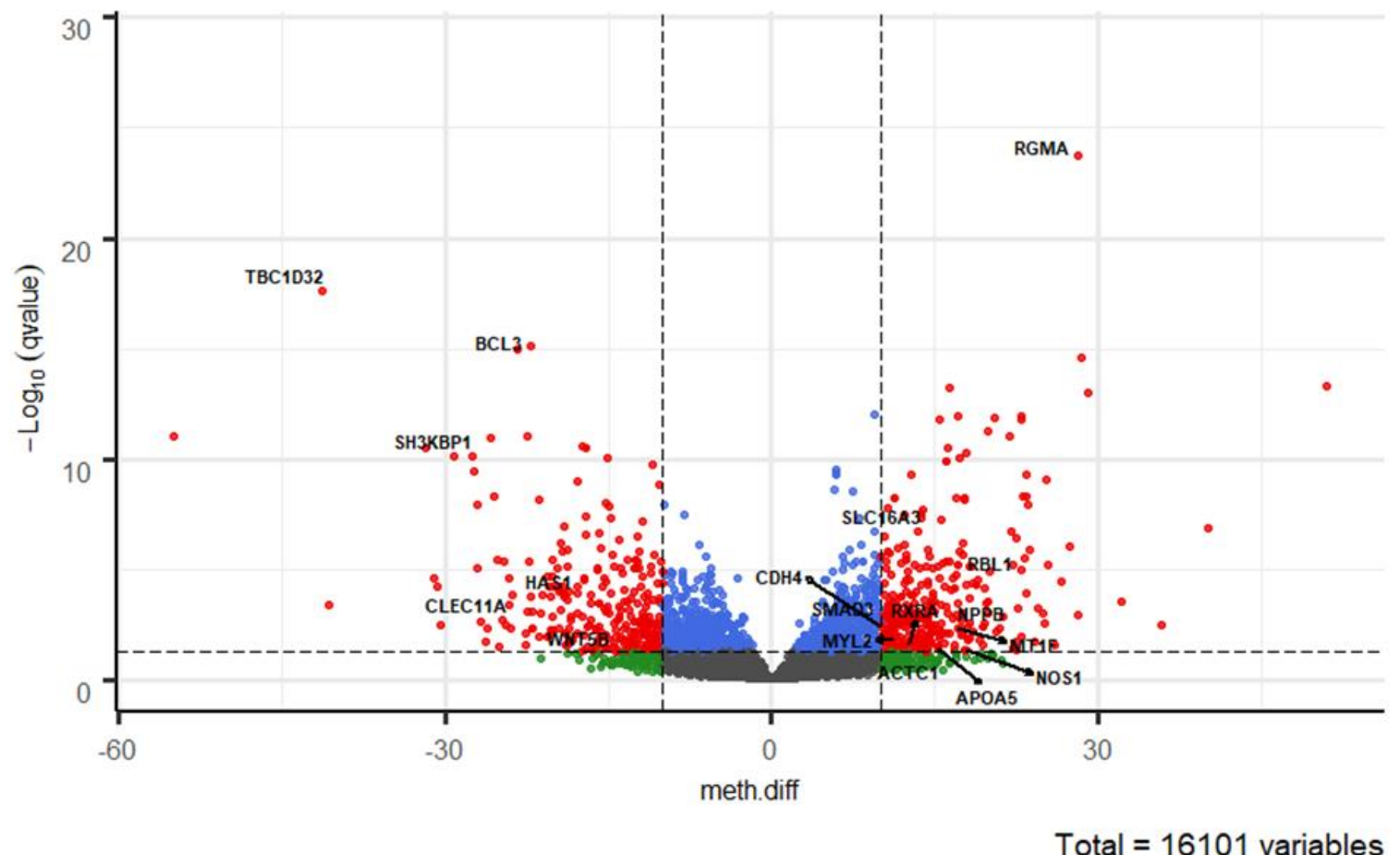

Figure 2. Volcano plot of promoter methylation profiles. The vertical lines $x=-10$ and $x=10$ represent our chosen methylation difference (meth.diff) cut-off value of $|10|$. meth.diff is calculated as described in the Methods. The horizontal line $(y=-\log 10(0.05)=1.3)$ shows our chosen q-value cut-off of 0.05 . The circles represent the 1601 promoters, of which 584 are differentially methylated (DM). Each circle in the volcano plot represents a promoter with its meth.diff and $-\log 10$ (q-value). Grey circles denote promoters that are not DM. Green circles represent promoters that are biologically, but not statistically significant. Blue circles depict the opposite trend. Red circles show promoters that are both statistically and biologically significant. Genes linked to DM promoters discussed in this manuscript are indicated on the plot.

We then functionally classified all genes associated with DM promoters according to pathways and functional categories (Figure 3 a-e, Figure S5) and identified their methylation direction in (Table S1). Key valve-related pathways such as Wingless/Integrated (WNT)-, Cadherin-, Transforming Growth Factor Beta (TGFB)-, Integrin-, Endothelin-, Platelet-Derived Growth Factor (PDGF)-, NOTCH signaling as well as angiogenesis and general transcription regulation were identified utilizing the PANTHER Pathway database (Figure 3 a, Table S2).

When the genes were classified by their molecular function, $69.5 \%$ of the genes had a binding and catalytic activity including key genes such as Nitric Oxide Synthase 1 (NOS1) (q-value $=0.04$, meth.diff $=$ $17.9 \%)$. Other genes exhibited transcription regulator-, translation regulator- and molecular function regulator activities. The latter category included relevant genes such as Apolipoprotein A5 (APOA5) (qvalue $=0.037$, meth.diff $=15.3 \%)$ and Natriuretic Peptide B $($ NPPB $)(q-$ value $=0.0027$, meth.diff $=$ 15.58\%) (Figure 3 b, Table S3).

Among the relevant biological processes categorizing the genes were "biological regulation" and "cellular component organization or biogenesis". The former included notable genes such as Metallothionein 1F $($ MT1F) $(\mathrm{q}$-value $=0.004$, meth.diff $=17.07 \%)$ and the latter included two pertinent 
medRxiv preprint doi: https://doi.org/10.1101/2020.09.10.20190546; this version posted September 11, 2020. The copyright holder for this preprint (which was not certified by peer review) is the author/funder, who has granted medRxiv a license to display the preprint in perpetuity.

It is made available under a CC-BY-NC-ND 4.0 International license .

ones namely Hyaluronan Synthase $1(\mathrm{HAS} 1)(\mathrm{q}$-value $=0.00015$, meth.diff $=22.15 \%)$ as well as Actin Alpha Cardiac Muscle 1 (ACTC1) (q-value $=0.049$, meth.diff $=11.23 \%$ ) (Figure 3 c, Table S4).

Genes were also grouped into relevant protein classes such as gene-specific transcriptional regulator proteins, which included SMAD Family Member 3 (SMAD3) (q-value $=0.0019$, meth.diff $=$ $10.25 \%$ ), cytoskeletal proteins, which contained Myosin Light Chain 2 (MYL2) (q-value $=0.013$, meth.diff $=11.14 \%$ ) and chromatin-binding protein, which encompassed RB Transcriptional Corepressor Like 1 $($ RBL1) (q-value $=9.5 e-06$, meth.diff $=22.98 \%)($ Figure 3 d, Table S5).

Finally, the cellular component categories into which the genes could be classified were membraneand extracellular regions among others. Relevant genes such as C-Type Lectin Domain Containing 11A $($ CLEC11A) $(\mathrm{q}$-value $=0.002$, meth.diff $=24.72 \%)$ were included in the latter and Solute Carrier Family 16 Member 3 (SLC16A3) (q-value $=1.78 \mathrm{e}-07$, meth.diff $=13.4 \%)$ in the former category $($ Figure 3 e,

Table S6).

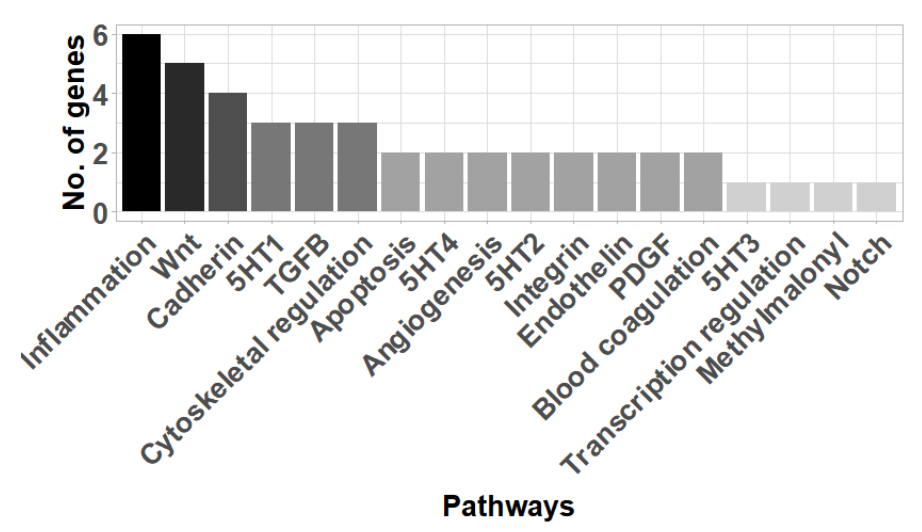

(a)

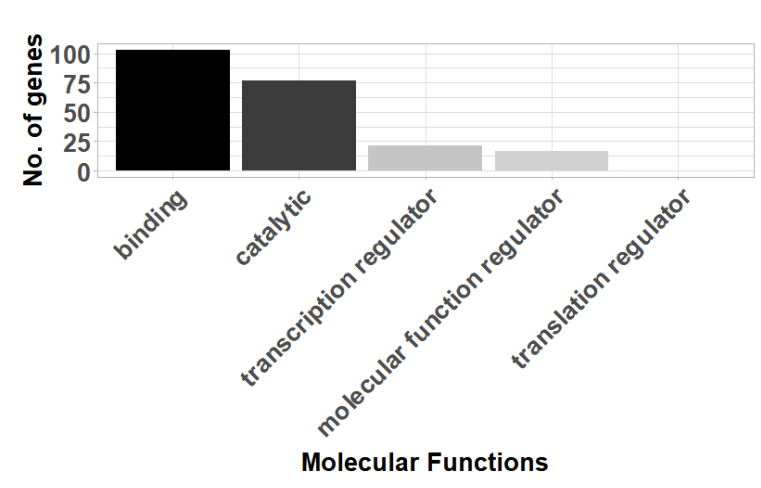

(b)

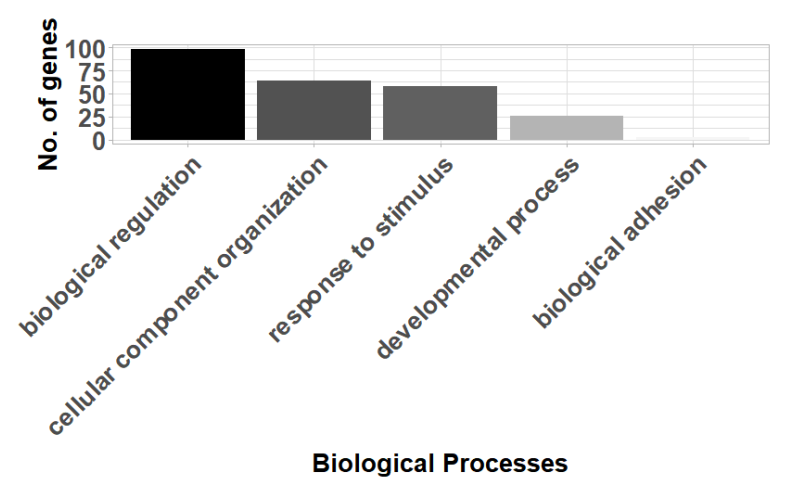

(c) 


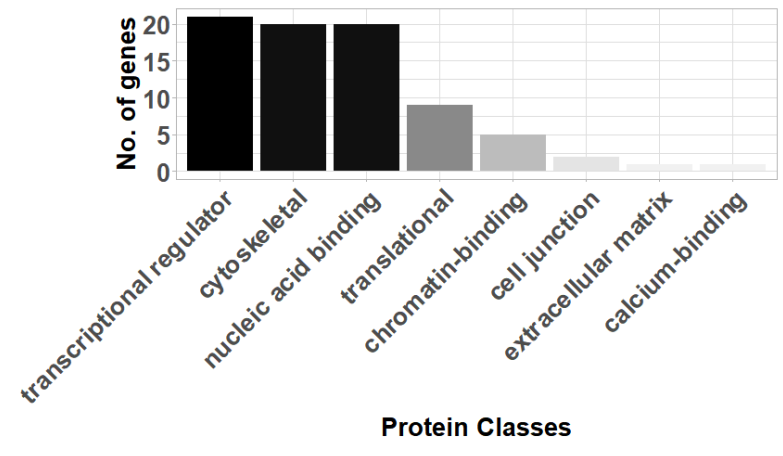

(d)

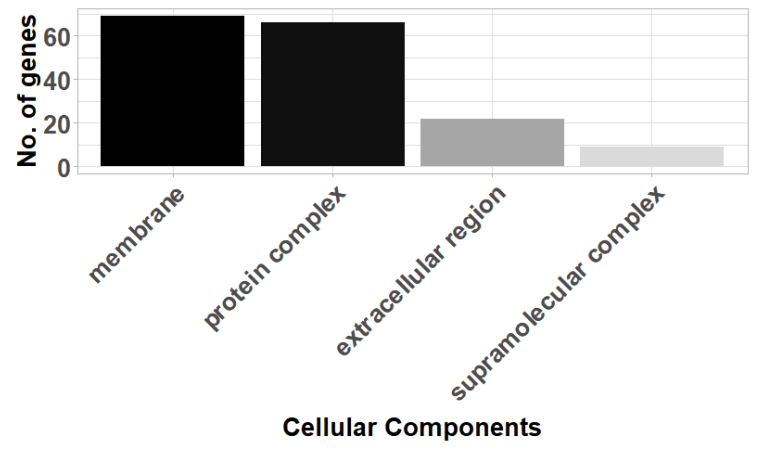

(e)

Figure 3. Functional classification of genes associated with differentially methylated promoters (q-value $<0.05 \&$ meth.diff $>|10|$ ) between aortic and mitral tissue according to (a) Pathways, (b) Molecular Functions, (c) Biological Processes, (d) Protein Classes and (e) Cellular Components (selected results, the remaining can be found in Figure S5- analysis performed using PANTHER).

3.2. Network analysis enabled a systems-based assessment and revealed additional valve-related pathways such as Hypoxia-Inducible Factor 1 (HIF-1) and Vascular Endothelial Growth Factor (VEGF) signaling

After functionally categorizing the genes, whose promoters were significantly DM between the aortic and mitral valves on a genome-wide level, we wanted to assess whether we can predict significantly enriched PPIs among those genes as well as the proteins that are necessary to interconnect them to enable a systems-level analysis.

For that purpose, we mapped those DM genes onto a generic PPI database (see Methods) and constructed a PPI network, which ultimately comprised 715 nodes (genes) of which 308 were seed genes and 2131 edges (PPIs) (Figure 4 a, Table S7). Among the network's constituent proteins were several hub nodes, the most connected of which were Ubiquitin C (UBC) (Betweenness centrality = 129377.98; Degree $=200)$, SMAD3 (Betweenness centrality = 27152.04; Degree $=75)$, Ubiquitin Like 4A (UBL4A) $($ Betweenness centrality $=13019.92$; Degree $=50$ ), Ribosomal Protein S3 (RPS3) (Betweenness centrality $=9508.1 ; \quad$ Degree $=50$ ), Retinoid X Receptor Alpha (RXRA) (Betweenness centrality $=12661.72$; Degree $=47)$ and SH3 Domain Containing Kinase Binding Protein 1 (SH3KBP1) $($ Betweenness centrality $=13005.65$; Degree $=44)($ Figure 4 a, Table S7). 


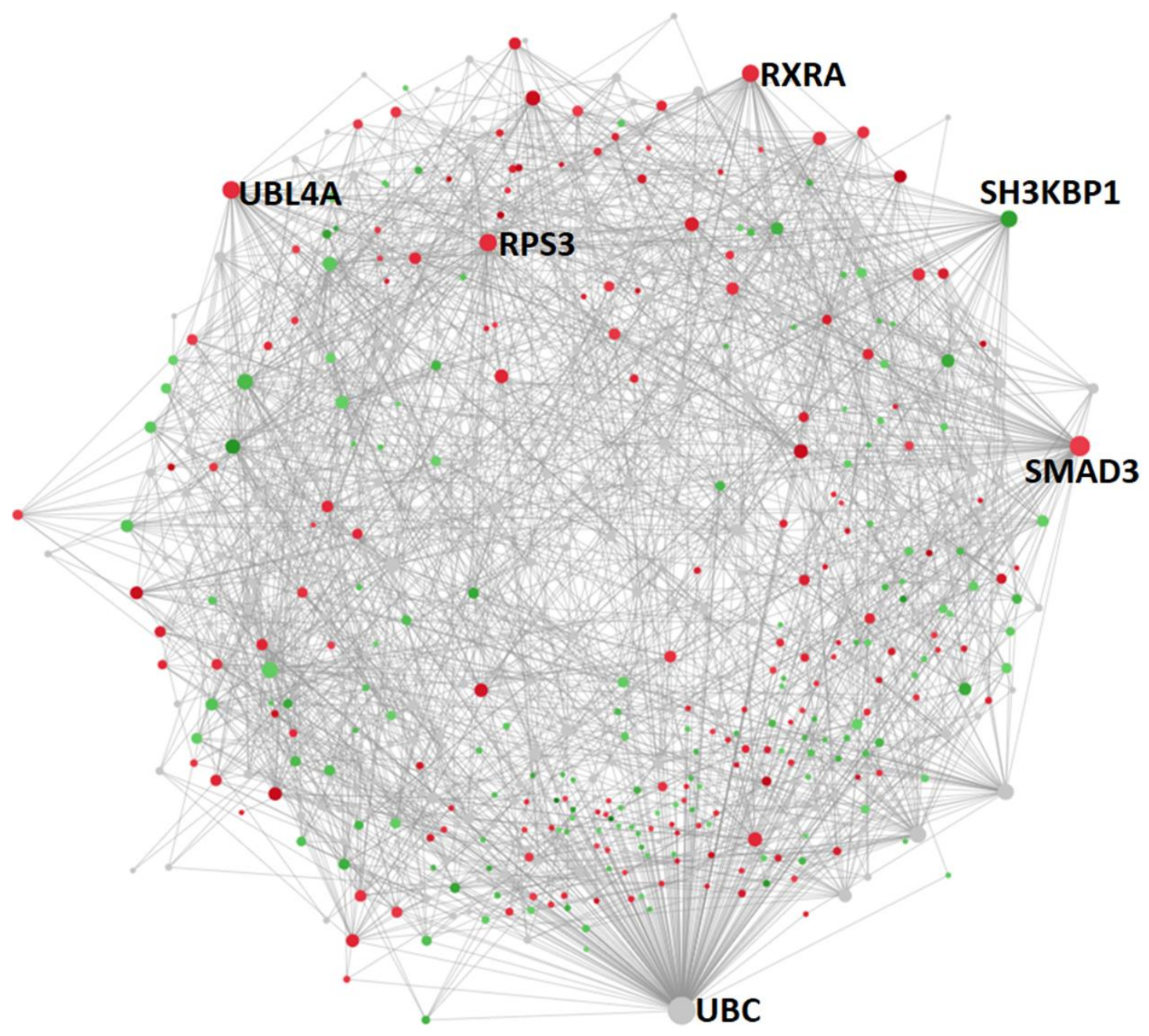

(a)
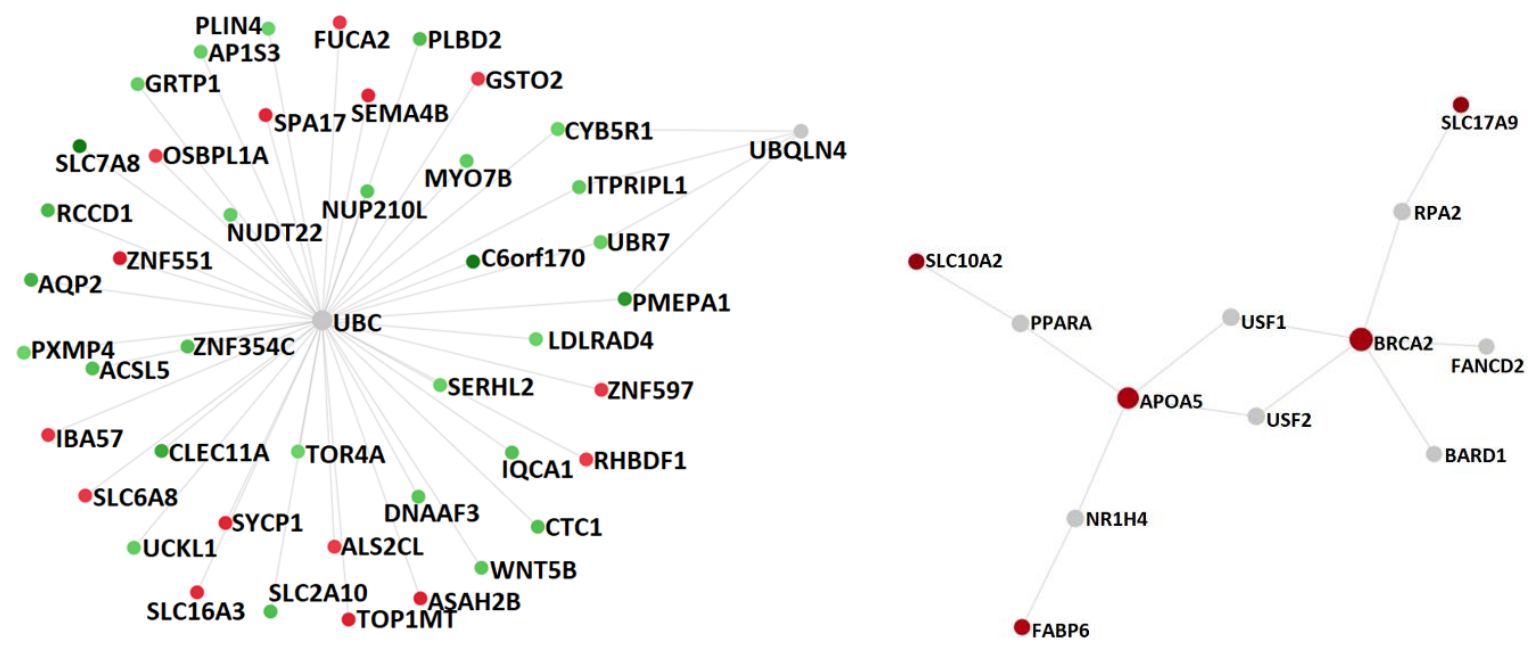

(b)

(c)

Figure 4. PPI networks constructed upon the genes associated with differentially methylated promoters between nondiseased aortic and mitral valve tissue and the proteins that are necessary to interconnect them: (a) complete network, 
It is made available under a CC-BY-NC-ND 4.0 International license .

(b) subnetwork 1 (p-value 3.04e-13) and (c) subnetwork 2 (p-value 0.047). Depicted nodes are classified according to their methylation direction: nodes representing genes showing increased methylation in mitral compared to aortic tissue (red), nodes depicting increased methylation in aortic versus mitral tissue (green) and nodes representing genes that are not part of the input dataset (grey). Node sizes are proportional to their betweenness centrality values. Betweenness centrality reflects the number of shortest paths passing through a node, while degree refers to the number of connections/edges/PPIs that a node has to other nodes. Hub nodes (a) UBC, SMAD3, UBL4A, RPS3, RXRA, (b) UBC and (c) BRCA2 and APOA5 can be clearly identified on the respective networks.

In addition to inspecting the topological properties of the constructed network, we performed a functional enrichment analysis of both the hyper- and hypomethylated proteins of the subnetwork as well as the proteins connecting them to investigate, whether we can detect relevant significantly enriched pathways and functions.

Many pathways, which are pertinent to valvular mechanisms, were identified via KEGG pathway enrichment analysis including apoptosis, Nuclear Factor Kappa-light-chain-enhancer of activated B cells (NF-Kb) signaling pathway, fluid shear stress and atherosclerosis, Tumor necrosis factor (TNF) signaling pathway, osteoclast differentiation, Interleukin 17 (IL-17) signaling pathway, HIF-1 signaling pathway, regulation of actin cytoskeleton, VEGF signaling pathway and TGFB signaling pathway (FDR $<0.05$, Table 2).

Table 2. List of pathways resulting from enrichment analysis of the network (Figure 4 a) constructed upon the genes associated with the differentially methylated hypo- and hypermethylated promoters using the KEGG pathway database.

\begin{tabular}{|c|c|c|c|c|c|c|c|}
\hline $\begin{array}{l}\text { KEGG } \\
\text { Pathways }\end{array}$ & Tot $^{1}$ & Exp $^{2}$ & Hits $^{3}$ & $\mathrm{Pval}^{4}$ & FDR $^{5}$ & $\begin{array}{l}\text { Seed } \\
\text { genes }\end{array}$ & Other genes ${ }^{8}$ \\
\hline Apoptosis & 136 & 7.91 & 31 & $\begin{array}{l}2.56 \mathrm{E} \\
-11\end{array}$ & $\begin{array}{l}6.8 \mathrm{E}- \\
10\end{array}$ & $\begin{array}{l}\text { CASP7, } \\
\text { TUBA8 } \\
\text {, CTSZ }\end{array}$ & $\begin{array}{l}\text { DDIT3, BIRC2, TNFRSF1A, } \\
\text { TRADD, IKBKG, RELA, NFKBIA, } \\
\text { ACTB, XIAP, TP53, RAF1, CTSB, } \\
\text { BIRC3, PIK3R1, FOS, NFKB1, } \\
\text { FAS, AKT1, MAPK1, IKBKB, } \\
\text { CTSD, TUBA1A, BCL2L11, } \\
\text { TRAF2, ITPR3, JUN, FASLG, } \\
\text { ACTG1 }\end{array}$ \\
\hline $\begin{array}{l}\text { NF-kappa } \\
\text { B signaling } \\
\text { pathway }\end{array}$ & 100 & 5.82 & 23 & $\begin{array}{l}8.40 \mathrm{E} \\
-09\end{array}$ & $\begin{array}{l}1.03 \mathrm{E}- \\
07\end{array}$ & $\begin{array}{l}\text { ZAP70, } \\
\text { TAB1 }\end{array}$ & $\begin{array}{l}\text { TRAF6, UBE2I, BIRC2, } \\
\text { TNFRSF1A, TRADD, IKBKG, } \\
\text { NFKB2, RELA, NFKBIA, XIAP, } \\
\text { BTK, IRAK1, MYD88, BIRC3, } \\
\text { NFKB1, IKBKB, PLCG1, LCK, } \\
\text { TRAF2, CSNK2B, LYN }\end{array}$ \\
\hline $\begin{array}{l}\text { Fluid shear } \\
\text { stress and } \\
\text { atheroscler } \\
\text { osis }\end{array}$ & 139 & 8.08 & 26 & $\begin{array}{l}8.57 \mathrm{E} \\
-08\end{array}$ & $\begin{array}{l}8.01 \mathrm{E}- \\
07\end{array}$ & $\begin{array}{l}\text { NQO1, } \\
\text { GSTO2 }\end{array}$ & $\begin{array}{l}\text { SUMO3, TNFRSF1A, IKBKG, } \\
\text { RELA, CAV1, ACTB, TP53, } \\
\text { HSP90AA1, SQSTM1, PIK3R1, } \\
\text { CTNNB1, FOS, NFKB1, AKT1, } \\
\text { SRC, PLAT, IKBKB, RAC1, }\end{array}$ \\
\hline
\end{tabular}


It is made available under a CC-BY-NC-ND 4.0 International license .

\begin{tabular}{|c|c|c|c|c|c|c|c|}
\hline & & & & & & & $\begin{array}{l}\text { SUMO1, SUMO2, HSP90AB1, } \\
\text { VEGFA, JUN, ACTG1 }\end{array}$ \\
\hline $\begin{array}{l}\text { TNF } \\
\text { signaling } \\
\text { pathway }\end{array}$ & 110 & 6.4 & 22 & $\begin{array}{l}2.55 \mathrm{E} \\
-07\end{array}$ & $\begin{array}{l}2.19 \mathrm{E}- \\
06\end{array}$ & $\begin{array}{l}\text { CASP7, } \\
\text { TAB1, } \\
\text { BCL3, } \\
\text { DNM1 } \\
\text { L }\end{array}$ & $\begin{array}{l}\text { BIRC2, TNFRSF1A, TRADD, } \\
\text { IKBKG, RELA, NFKBIA, BIRC3, } \\
\text { PIK3R1, FOS, NFKB1, FAS, AKT1, } \\
\text { MAPK1, IKBKB, CREB1, TRAF2, } \\
\text { CEBPB, JUN }\end{array}$ \\
\hline $\begin{array}{l}\text { Osteoclast } \\
\text { differentiat } \\
\text { ion }\end{array}$ & 128 & 7.44 & 23 & $\begin{array}{l}1.01 \mathrm{E} \\
-06\end{array}$ & $\begin{array}{l}7.32 \mathrm{E}- \\
06\end{array}$ & $\begin{array}{l}\text { TAB1, } \\
\text { LCP2, } \\
\text { FHL2 }\end{array}$ & $\begin{array}{l}\text { TRAF6, TNFRSF1A, IKBKG, } \\
\text { NFKB2, RELA, NFKBIA, BTK, } \\
\text { SQSTM1, PIK3R1, FOS, NFKB1, } \\
\text { AKT1, GRB2, MAPK1, IKBKB, } \\
\text { RAC1, CREB1, LCK, TRAF2, JUN }\end{array}$ \\
\hline $\begin{array}{l}\text { IL-17 } \\
\text { signaling } \\
\text { pathway }\end{array}$ & 93 & 5.41 & 19 & $\begin{array}{l}1.20 \mathrm{E} \\
-06\end{array}$ & $\begin{array}{l}8.31 \mathrm{E}- \\
06\end{array}$ & CSF3 & $\begin{array}{l}\text { TRAF6, TRADD, IKBKG, RELA, } \\
\text { NFKBIA, HSP90AA1, FOS, } \\
\text { NFKB1, MAPK1, IKBKB, MAPK6, } \\
\text { GSK3B, ELAVL1, S100A9, } \\
\text { HSP90AB1, TRAF2, CEBPB, JUN }\end{array}$ \\
\hline $\begin{array}{l}\text { HIF-1 } \\
\text { signaling } \\
\text { pathway }\end{array}$ & 100 & 5.82 & 19 & $\begin{array}{l}3.78 \mathrm{E} \\
-06\end{array}$ & $\begin{array}{l}2.36 \mathrm{E}- \\
05\end{array}$ & LDHA & $\begin{array}{l}\text { GAPDH, VHL, CREBBP, RELA, } \\
\text { STAT3, ERBB2, EGFR, PIK3R1, } \\
\text { NFKB1, HIF1A, AKT1, MAPK1, } \\
\text { CDKN1A, EP300, CUL2, PLCG1, } \\
\text { ENO3, VEGFA }\end{array}$ \\
\hline $\begin{array}{l}\text { Regulation } \\
\text { of actin } \\
\text { cytoskeleto } \\
\mathrm{n}\end{array}$ & 214 & 12.4 & 29 & $\begin{array}{l}1.56 \mathrm{E} \\
-05\end{array}$ & $\begin{array}{l}8.69 \mathrm{E}- \\
05\end{array}$ & $\begin{array}{l}\text { MYL2, } \\
\text { PAK6, } \\
\text { LIMK1, } \\
\text { F2R, } \\
\text { FGD1, } \\
\text { FGD3 }\end{array}$ & $\begin{array}{l}\text { MYL12A, ACTB, WAS, PPP1CA, } \\
\text { RAF1, CRK, EGFR, PIK3R1, SRC, } \\
\text { MAPK1, IQGAP1, SOS1, RAC1, } \\
\text { CDC42, FN1, WASL, CRKL, } \\
\text { PPP1CC, PAK2, GIT1, VAV2, } \\
\text { ACTG1, ARHGEF7 }\end{array}$ \\
\hline $\begin{array}{l}\text { VEGF } \\
\text { signaling } \\
\text { pathway }\end{array}$ & 59 & 3.43 & 10 & $\begin{array}{l}0.001 \\
92\end{array}$ & $\begin{array}{l}0.0067 \\
1\end{array}$ & NA & $\begin{array}{l}\text { RAF1, PIK3R1, AKT1, SRC, } \\
\text { MAPK1, RAC1, CDC42, PLCG1, } \\
\text { PLA2G4A, VEGFA }\end{array}$ \\
\hline $\begin{array}{l}\text { TGF-beta } \\
\text { signaling } \\
\text { pathway }\end{array}$ & 92 & 5.35 & 13 & $\begin{array}{l}0.002 \\
41\end{array}$ & $\begin{array}{l}0.0081 \\
7\end{array}$ & $\begin{array}{l}\text { RGMA, } \\
\text { RBL1, } \\
\text { SMAD3 } \\
\text {, E2F4, } \\
\text { HAMP }\end{array}$ & $\begin{array}{l}\text { CREBBP, MYC, SMAD2, SMAD7, } \\
\text { MAPK1, SP1, EP300, CUL1 }\end{array}$ \\
\hline
\end{tabular}

1 "Tot" refers to the total number of genes that belong to the particular KEGG pathway as per the chosen reference list of genes, which is hg19 in our case, ${ }^{2}$ "Exp" denotes the number of genes to be expected in our gene list for the particular KEGG pathway, "Hits" describes the number of genes in our list that map to the particular KEGG pathway, 4 "Pval" is equivalent to the enrichment p-value computed using the hypergeometric test (see Methods), "FDR" stands for false discovery rate, which is the method used to correct the corresponding p-value for multiple testing, 6 "Seed genes" represent genes associated with significantly differentially hyper- and hypomethylated promoters and 7 "Other genes" denote genes that are part of the minimum non-seed genes that are necessarily required to connect the seed genes to construct the network. The methylation direction of the seed genes can be found in Table S1. 
To investigate whether relevant significantly enriched pathways are present independent of the choice of the pathway database, we furthermore performed Reactome enrichment analysis, which exclusively highlighted additional key valve-related pathways such as immune response, regulation of lipid metabolism, PDGF, NOTCH1, Fibroblast Growth Factor Receptor (FGFR) and transcription (FDR < 0.05, Table S8). Similar to KEGG, it showed enrichment for apoptosis-, TFGB-, interleukin- and hypoxiarelated pathways (Table 2, Table $\mathbf{S 8}$ ).

After inspecting significant valve-related pathways, we checked whether there are enriched biological processes, molecular functions and cellular components related to the molecular regulation of valve-related processes based on GO databases. Relevant biological processes included transcription, apoptosis, growth factor signaling as well as regulation of cellular component organization (FDR $<0.05$, Table S9). Molecular functions associated with transcription as well as histone acyltransferase activity such as chromatin-, histone deacetylase-, TF-, SMAD- and NF- $\kappa B$-binding were among the pertinent significantly enriched molecular functions ( $F D R<0.05$, Table S10). Finally, the most relevant significantly enriched cellular components were Transcription Factor II D (TFIID) complex, spliceosomal complex, chromatin, histone deacetylase complex as well as actin cytoskeleton (FDR $<0.05$, Table S11).

In addition to examining the network structure as a whole, we performed a module analysis (see Methods), to identify subnetworks that show a significantly increased connection density compared to other modules of the parent network. The first identified subnetwork (p-value 3.04e-13) comprised 45 nodes, of which 43 were seed genes and contained the following hub nodes: UBC, also identified as a hub protein of the parent network (Betweenness centrality $=43$; Degree $=939)$ and Ubiquilin $4($ UBQLN4), not identified previously (Betweenness centrality $=3$; Degree $=4$ ) (Figure 4 b, Table S12, Table S13).

The second subnetwork (p-value 0.047) contained 12 nodes, of which 5 were seed genes with Breast And Ovarian Cancer Susceptibility Protein 2 (BRCA2) (Betweenness centrality = 33.5; Degree = 5) as well as APOA5 (Betweenness centrality $=32.5$; Degree $=4$ ) being its main hub proteins. Interestingly, all of the module's constituent seed nodes exhibited increased methylation in mitral compared to aortic tissue (Figure 4 c, Table S14). Relevant enriched pathways in this module included homologous recombination (KEGG/Reactome) and Peroxisome Proliferator-Activated Receptor (PPAR) signaling pathway (KEGG) (FDR < 0.05, Table S15). The module's biological processes contained lipid homeostasis and cellular response to external stimulus (FDR $<0.05$, Table S15). Finally, the most relevant enriched molecular functions encompassed DNA-, enzyme- and TF- binding (FDR $<0.05$, Table S15).

3.3. Global analysis of detected pathways and genes shows the role of methylation in EMT and ECM remodeling

All the utilized analysis methods of genes and pathways show that DNA methylation plays a crucial role in valve development and disease. Indeed, some of the detected genes and pathways are involved in developmental processes such as cardiogenesis, EMT and protein QC and/or diseases such as myxomatous mitral valve (MMV), BAV and AD (Table 3,Table 4).

Table 3. Genes associated with differentially methylated promoters between aortic and mitral valve tissue and their involvement in valve development and disease.

\begin{tabular}{llll}
\hline Gene & Description & Development & Disease \\
\hline
\end{tabular}


medRxiv preprint doi: https://doi.org/10.1101/2020.09.10.20190546; this version posted September 11, 2020. The copyright holder for this preprint (which was not certified by peer review) is the author/funder, who has granted medRxiv a license to display the preprint in perpetuity.

It is made available under a CC-BY-NC-ND 4.0 International license .

\begin{tabular}{|c|c|c|c|}
\hline NOS1 & nitric oxide synthase 1 (neuronal) & heart [46] & $\mathrm{BAV}^{1}[46]$ \\
\hline ACTC1 & actin, alpha, cardiac muscle 1 & heart [47] & $\mathrm{MMV}^{2}[49]$ \\
\hline MYL2 & myosin, light chain 2 , regulatory, cardiac & heart [48] & \\
\hline MT1F & metallothionein $1 \mathrm{~F}$ & & MMV [50] \\
\hline CLEC11A & C-Type lectin domain containing $11 \mathrm{~A}$ & & MMV [51] \\
\hline RBL1 & retinoblastoma-like 1 (p107) & & $\mathrm{BAV}[52]$ \\
\hline SLC16A3 & $\begin{array}{l}\text { solute carrier family } 16, \text { member } 3 \\
\text { (monocarboxylate transporter) }\end{array}$ & & $\mathrm{BAV}[53], \mathrm{AS}^{3}[59]$ \\
\hline NPPB & natriuretic peptide $B$ & $\mathrm{EMT}^{4}[54]$ & $\mathrm{MR}^{5}[55]$ \\
\hline $\mathrm{CDH} 4$ & cadherin 4, type 1, R-cadherin (retinal) & valve [56] & \\
\hline HAS1 & hyaluronan synthase 1 & & $\mathrm{CAVD}^{6}[57]$ \\
\hline WNT5B & $\begin{array}{l}\text { wingless-type MMTV integration site } \\
\text { family, member 5B }\end{array}$ & & CAVD [58] \\
\hline $\begin{array}{l}\text { Ubiquitin- } \\
\text { related } \\
\text { genes }\end{array}$ & & $\begin{array}{l}\text { protein } \mathrm{QC}^{7} \text { in } \\
\text { the heart }[62]\end{array}$ & $\begin{array}{l}\text { BAVs [60], atherosclerosis } \\
\text { [61] }\end{array}$ \\
\hline SMAD3 & SMAD family member 3 & $\begin{array}{l}\text { cardio-genesis } \\
\text { [63] }\end{array}$ & $\mathrm{AD}^{8}[64]$ \\
\hline RXRA & retinoid $\mathrm{X}$ receptor, alpha & & Valve malformation [65] \\
\hline SH3KBP1 & SH3-domain kinase binding protein 1 & & CAVD [66] \\
\hline APOA5 & apolipoprotein A-V & & AS [67-69] \\
\hline
\end{tabular}

${ }^{1}$ BAV: bicuspid aortic valve; ${ }^{2}$ MMV: myxomatous mitral valve; ${ }^{3}$ AS: aortic valve stenosis; ${ }^{4}$ EMT: endothelial mesenchymal trans-differentiation; ${ }^{5} \mathrm{MR}$ : mitral valve regurgitation; ${ }^{6} \mathrm{CAVD}$ : calcific aortic valve disease; ${ }^{7} \mathrm{QC}$ : quality control; ${ }^{8} \mathrm{AD}$ : thoracic aortic aneurysm and dissection.

Table 4. Pathways involving the genes associated with the differentially methylated promoters between aortic and mitral valve tissue and their implication in valve development and disease.

\begin{tabular}{llll}
\hline Pathway & Description & Development & Disease \\
\hline TGFB signaling & $\begin{array}{l}\text { Transforming growth } \\
\text { factor beta signaling }\end{array}$ & EMT $^{1}[3]$ & $\operatorname{ECM}^{2}$ remodeling [71], \\
& & $\operatorname{MVP}^{3}$ [72], AS ${ }^{4}[73]$ \\
NOTCH signaling & & EMT [3], [70] & $\operatorname{BAV}^{5}$ [70] and AS [70] \\
FGF signaling & $\begin{array}{l}\text { Fibroblast growth } \\
\text { factor signaling }\end{array}$ & EMT [74] & Valve malformation [74] \\
& & &
\end{tabular}


WNT signaling

Cadherin signaling

PDGF signaling

VEGF signaling

Integrin signaling

HIF-1 signaling

Angiogenesis

IL-17 signaling

$\mathrm{NF}-\kappa \mathrm{B}$ signaling

TNF signaling

Osteoclast

differentiation

pathways

Endothelin signaling

Apoptotic pathways

PPAR signaling heart, EMT [3,58]

EMT [75]

Platelet-derived

heart [76]

growth factor

EMT [3]

EMT [3], cell-ECM

$[77,78]$

$\mathrm{RMV}^{6}, \mathrm{MMV}^{7}$ [79]

RMV [80]

$\mathrm{IE}^{8}[81]$

AS [82]

AS [83]

AS [84]

VICs ${ }^{9}$ regulation by

AS [85]

VECs ${ }^{10}[87]$

AS [86]

${ }^{1}$ EMT: endothelial mesenchymal trans-differentiation; ${ }^{2}$ ECM: extracellular matrix; ${ }^{3}$ MVP: mitral valve prolapse; ${ }^{4}$ AS: aortic valve stenosis; ${ }^{5} \mathrm{BAV}$ : bicuspid aortic valve; ${ }^{6} \mathrm{RMV}$ : rheumatic mitral valve; ${ }^{7} \mathrm{MMV}$ : myxomatous mitral valve; ${ }^{8}$ IE: infective endocarditis; ${ }^{9}$ VICs: valve interstitial cells; ${ }^{10}$ VECs: valve endothelial cells.

We further generated a GOChord plot to link the pathways in Table 4 to their constituent genes, which are associated with DM promoters (Figure $5 \mathbf{a}$ ). The plot revealed several pathways sharing the same genes, such as NF-кB signaling, TNF signaling and osteoclast differentiation, which contain TGF-Beta Activated Kinase 1 Binding Protein 1 (TAB1) and Integrin- and PDGF signaling, which include Collagen Type V Alpha 3 (COL5A3) (Figure 5 a).

A GOCircle plot visualizes the significance of each pathway in Table $\mathbf{4}$ and to show the direction of promoter methylation of their constituent genes (Figure 5 b). The most significant pathways in Table 4 were $\mathrm{NF}-\kappa \mathrm{B}, \mathrm{TNF}$ signaling and osteoclast differentiation, which share TAB1 (Figure 5 a) and are implicated in aortic stenosis (AS) (Table 4). 


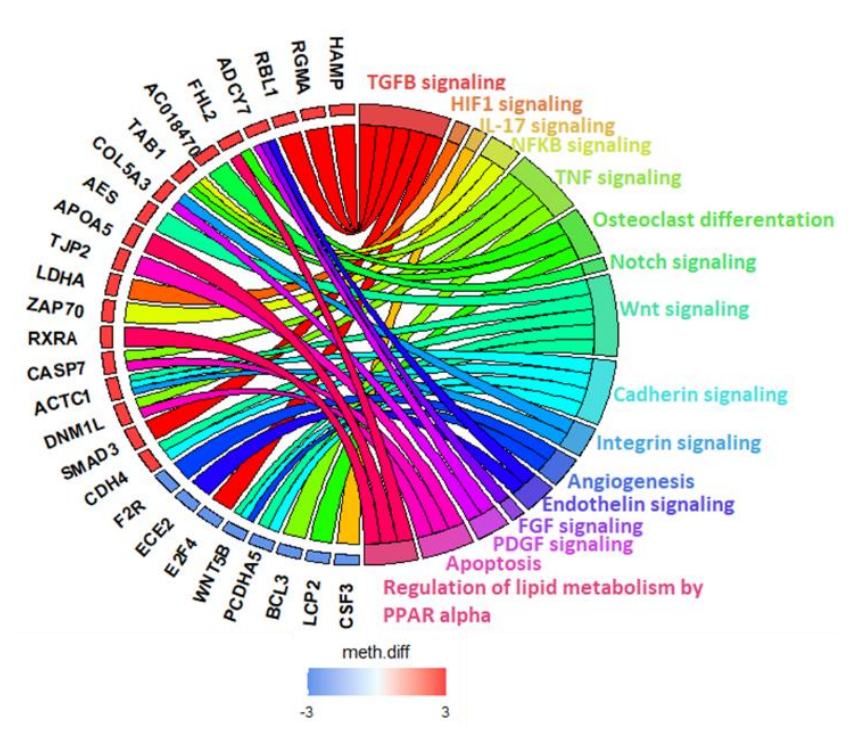

(a)

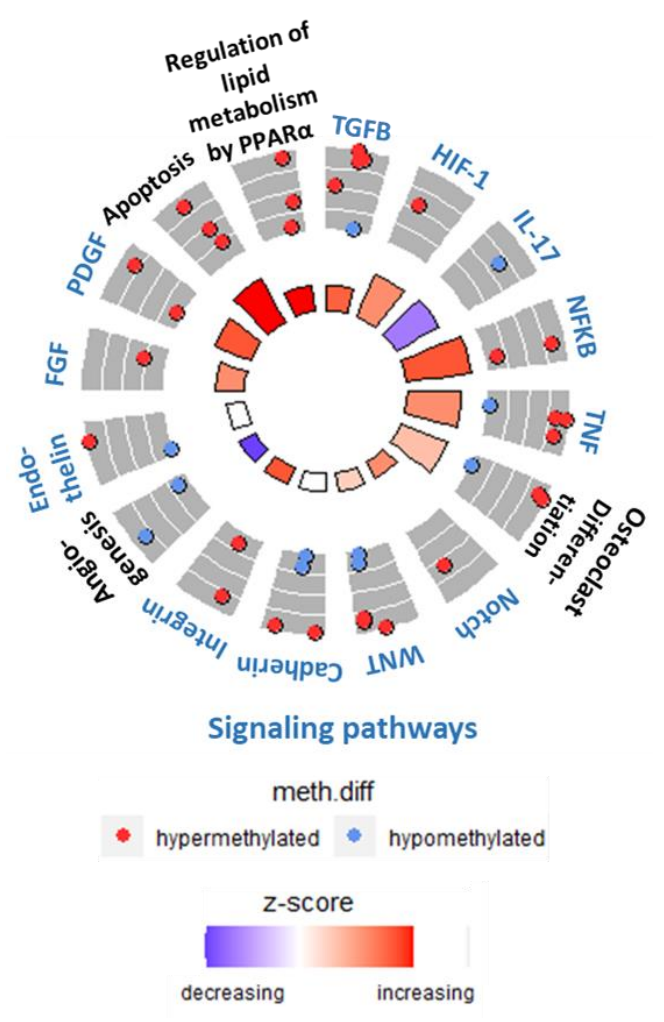

(b)

Figure 5. (a) GOChord plot linking selected pathways to their constituent genes, which are associated with DM promoters. Blue-to-red colors next to the selected genes reflect their meth.diff values. (b) GOCircle plot representing the relevant pathways and their constituent genes that are associated with DM promoters. The inner circle consists of bar plots, whose heights reflect the significance of the pathway and whose color reflect the $\mathrm{z}$-score, which approximates the overall direction of change in methylation for each pathway. The outer circle shows scatterplots of the meth.diff values of each of the pathways' constituent genes.

\section{Discussion}

This study explores the DNA methylation landscape in human non-diseased heart valves. Heart valves have a complex structure and function that are sensitive to their environment and exhibit characteristic phenotypic and functional differences. Valve-type specific differences begin to appear during valve formation and development and are expressed in the valves' distinct anatomical structures, environmental milieus and susceptibility to disease. In this work we focus on two of the four valves, the mitral and aortic valves and their epigenetic profiles. On the developmental level, the mature mitral valve is formed from atrioventricular (AV) cushions generated by EMT, while the mature aortic valve is created from cushions deposited at the outflow tract (OFT) [30]. On the anatomical level, the mitral and aortic valves differ in that the mitral valve is composed of two leaflets, the anterior and posterior leaflets, while the aortic valve is composed of three cusps, the left-, right- and non-coronary cusps [31]. Additionally, the mitral valve is anchored by a specialized structure consisting of the chordae tendineae and papillary muscles, whereas the distinct shape of the aortic valve provides a unique self-contained support configuration [32]. The entire aortic valve machinery is dynamic as its components move spatially as well 
It is made available under a CC-BY-NC-ND 4.0 International license .

as alter their shape and size in response to different conditions of the cardiac cycle [33]. Due to this dynamism it is described as the "living aortic valve"[34]. On the hemodynamic level, the valves are exposed to different forces with the mitral valve, being exposed to higher pressures than the aortic valve [1]. All the described above makes the mitral and aortic valves susceptible to different diseases with the mitral valve being more prone to mitral valve prolapse (MVP), rheumatic mitral valve (RMV) stenosis, degenerative mitral regurgitation (MR) and MMV disease, whereas the aortic valve being more predisposed to AS, calcific aortic valve disease (CAVD) and BAV disease [35]. To understand the aforementioned differences that exist despite having the same genetic basis, it is important to understand mechanisms of epigenetic regulation of major valve-type specific affected genes and pathways. Our work is focused on profiling genome-wide DNA methylation patterns based on a small cohort of matched non-diseased donor heart valves to enable the characterization of valve-type associated differences as well as their separation from valve disease-related ones. By having matched donors, confounding effects such as gender, age, valve/patient health status are reduced further highlighting the accuracy of the generated aortic and mitral valve methylation profiles.

We used RRBS to measure DNA methylation as it targets CpG-rich islands and promoters genomewide [36]. It is crucial to couple this sequencing method with suited bioinformatics workflows, that rely on rigorous QC of RRBS-characteristic issues as well as of bisulfite sequencing-specific parameters such as the efficiency of bisulfite conversion [37]. RRBS thus can allow for a comprehensive view not limited by predefined sets of $\mathrm{CpG}$ loci probes [38].

In this study, 584 of 1601 promoters were found to be DM between aortic and mitral tissue and their associated genes associated were found to be implicated in valvular health and disease mechanisms. RGMA was associated with the most significantly DM promoter. It is a member the RGM protein family, the first known BMP selective co-receptor family able to induce BMP signaling that is dysregulated in CAVD [39,40]. TBC1D32, the gene associated with the second most DM promoter, is implicated in the pathogenesis of ciliopathies in humans [41], which are caused by defects in the human primary cilium known to play a role in establishing left-right asymmetry during heart development [42], to restrain ECM production during physiological aortic valve development and to play a role in the etiology of BAV in humans [43]. Finally, BCL3, the gene associated with the third most DM promoter, is known to play a role in atherosclerosis [44], with atherosclerosis-like lesions potentially leading to AS [45].

Further genes, that were associated with DM promoters (summarized in Table 3) include NOS1, ACTC1 and MYL2, which play key roles in heart development [46-48], with ACTC1 additionally being implicated in MMV and NOS1 in BAV [46,49]. MT1F and CLEC11 further contribute to MMV [50,51], while RBL1 and SLC16A3 to BAV [52,53]. NPPB is involved in EMT by exhibiting excessive synthesis of the cardiac jelly, a precursor of the cushions, in zebrafish and is overexpressed in the ventricles of patients with chronic volume overload caused by regurgitant mitral valve lesions [54,55]. Cadherin-4 (CDH4) is both significantly DM and expressed during the development of embryonic mice [56]. Finally, HAS1 and Wingless/Integrated 5B (WNT5B) contribute to CAVD [57,58], and SLC16A3 to AS [59].

The network constructed upon the genes linked to DM promoters identified hub proteins known to be involved in different aortic and mitral valve mechanisms. UBC and UBL4A, the two most connected hub genes of the network, belong to the ubiquitin family, whose members play a role in BAVs as well as in atherosclerosis $[60,61]$. The network's first submodule was additionally entirely centered around UBC further highlighting the importance of the ubiquitin system, which is key to performing protein QC in the heart [62]. SMAD3, the second most connected hub node, plays an important role in cardiogenesis [63], and is linked to thoracic aortic aneurysm and dissection [64]. RXRA, a member of the RA signaling 
It is made available under a CC-BY-NC-ND 4.0 International license .

pathway and the network's third hub node, is linked to OFT and AV canal malformations, which influence proper aortic and mitral valve development [65]. Finally, the hub node SH3KBP1 is implicated in CAVD [66]. The second submodule of the network contained only two hub nodes APOA5 and BRCA2. Dyslipidemia linked to Lipoprotein a (LPA)-associated APOA5 has been detected in AS, with the reduction of LPA levels via PSCK9 inhibitors constituting promising therapeutic avenues for AS treatment [67-69]. BRCA2, has not been associated with valvular mechanisms in the literature and thus should be further investigated.

Detected pathways were relevant to valvular development and disease (Table 4). For example, TGFB- and NOTCH signaling pathways activate EMT by downregulating VE-Cadherin [3,70], which decreases cell adhesion of the transforming endocardial cells enabling them to break away from the endocardium and to migrate into the cardiac jelly, where they can transform into mesenchyme cells creating cushions that expand and fuse to ultimately form cardiac valves [3]. TGFB signaling is also implicated in pathological ECM remodeling [71], MVP [72], AS [73], and NOTCH pathways in BAV and AS [70]. FGF signaling further promotes OFT myocardial cell invasion to the cardiac cushion during EMT, with its disruption leading to malformed OFT valves in mice [74]. Canonical WNT- and Cadherin signaling add to cushion development and remodeling during EMT [3,75], with WNT pathways being additionally implicated in valve stratification and well as in the patterning of the heart forming field [3]. Similar to WNT- and Cadherin-, the PDGF signaling pathway is also involved in cardiogenesis, particularly in the formation of the primordial heart tube [76]. Both the VEGF- and Integrin signaling pathways contribute to post-EMT maturation, in that the former establishes an equilibrium between proliferation and differentiation of cells in the cushion [3], and the latter enables ECM remodeling through the generation of a mechano-transducing network that connects the cells to the ECM providing a link that relays external metabolic and hemodynamic factors [77,78]. HIF-1 signaling is involved in pathological ECM remodeling associated with RMV and MMV disease [79]. Aberrant angiogenesis and IL-17 signaling are also implicated in RMV and infective endocarditis (IE), respectively [80,81]. NF- $\mathrm{BB}-$, TNF-, osteoclast differentiation-, Endothelin and Apoptotic pathways are involved in AS [82-86], with the Endothelin pathway additionally being implicated in the regulation of VICs by VECs [87]. Finally, the detected PPAR signaling pathway is linked to lipid metabolism and is enriched among other lipid-related genes in the second mitral valve-specific subnetwork [88]. The enrichment of PPAR signaling, the uniform increased methylation of the subnetwork's constituent genes in mitral compared to aortic valves and APOA5 being a hub node, indicate that this subnetwork exhibits major methylation alterations related to the metabolism of lipids. The regulation and expression of lipid-related genes need to be further dissected as it has been reported in a previous study that increased fatty infiltration of valves is observed in MVP [89].

Our analysis provided a comprehensive catalogue of genes and pathways that are differentially regulated between aortic and mitral valves, establishing the basis for upcoming whole-genome bisulfite sequencing (WGBS) studies to additionally interrogate methylation of gene-bodies and other non-promoter regions. Additional insights can be obtained from histone-modification and RNA-based experiments as well as the interaction of such epigenetic mechanisms with DNA methylation. Functional validation of genes and pathways of interest on the transcriptomic and proteomic level will confirm candidate DM biomarkers, which can serve as potential drug targets. Additionally, the same analysis on the VIC level will be done to confirm cell-type specific signals that might have been affected by the tissue's intrinsic cell heterogeneity. As mentioned above, valves have a unique trilamellar structure housing VICs in a complex consisting of an ECM covered by VECs, all of which contribute to the detected differences. Such analysis will provide novel mechanistic insights into the distinct roles of the individual components. 
It is made available under a CC-BY-NC-ND 4.0 International license .

Limitations - In this study, due to the scarcity of human non-diseased donor heart valves, a relatively small number of valves was examined $(n=12)$ and two of the four heart valves were studied. Further validation is required to evaluate the clinical significance of the methylation markers identified. An enhancement of the methodology used in this manuscript will be utilized in future studies for example by performing WGBS.

\section{Conclusion}

To conclude, this is the first study that explores the genome-wide DNA methylation landscape characterizing human non-diseased aortic and mitral valves. By investigating genes that are linked to DM promoters and their associated pathways, we discovered that the cells as well as the ECM of the aortic and mitral valve have different methylation signatures. The detected pathways included TGFB-, NOTCH-, FGF-, WNT-, Cadherin- and VEGF signaling pathways associated with EMT, Integrin- and HIF-1 signaling linked to ECM remodeling and NF- $\kappa \mathrm{B}-$, TNF-, osteoclast differentiation, Endothelin- and IL-17 signaling observed in aortic and mitral valve disease. Especially with the increasing incidence and prevalence of valve disease worldwide due to the world's increasing population age in developed and the failure to address RHVD in low and middle-income countries (LMICs) [6], it is very important to acquire a better understanding of the genetic and epigenetic make-up of cardiac valves and how they are influenced by local conditions, environmental factors and ethnicities as this will affect the development of preventative and therapeutic strategies.

6. Supplementary Materials: Supplementary materials can be found online.

7. Author Contributions: Conceptualization, Najma Latif, Yasmine Aguib and Magdi Yacoub; Data curation, Sarah Halawa; Formal analysis, Sarah Halawa; Funding acquisition, Yasmine Aguib and Magdi Yacoub; Investigation, Sarah Halawa, Najma Latif, Yuan-Tsan Tseng and Adrian H. Chester; Methodology, Sarah Halawa, Najma Latif, Ahmed Moustafa, Yasmine Aguib and Magdi Yacoub; Project administration, Najma Latif and Yasmine Aguib; Resources, Najma Latif, Ayman M. Ibrahim, Adrian H. Chester and Yasmine Aguib; Software, Sarah Halawa; Supervision, Ahmed Moustafa, Yasmine Aguib and Magdi Yacoub; Validation, Sarah Halawa; Visualization, Sarah Halawa, Ahmed Moustafa and Yasmine Aguib; Writing - original draft, Sarah Halawa; Writing - review \& editing, Najma Latif, Ahmed Moustafa, Yasmine Aguib and Magdi Yacoub.

8. Funding: This research was funded by Magdi Yacoub Institute (MYI) and Magdi Yacoub Foundation (MYF). Sarah Halawa was partially supported by and Al Alfi Foundation (Al Alfi PhD Fellowship in Applied Sciences and Engineering).

9. Acknowledgments: We kindly acknowledge Engineer Yehia Raef (Aswan Heart Centre) for supporting this work with scientific data management. We also thank Professor John Chambers and his team for hosting part of Sarah Halawa's training.

10. Conflicts of Interest: The authors declare no conflict of interest.

\section{References}

[1] Chester AH, El-Hamamsy I, Butcher JT, Latif N, Bertazzo S, Yacoub MH. The living aortic valve: From molecules to function. Glob Cardiol Sci Pract 2014;2014:52-77. 
https://doi.org/10.5339/gcsp.2014.11.

[2] Yacoub MH. In Search of Living Valve Substitutes. J Am Coll Cardiol 2015;66:889-91. https://doi.org/10.1016/j.jacc.2015.07.007.

[3] Armstrong EJ, Bischoff J. Heart valve development: Endothelial cell signaling and differentiation. Circ Res 2004;95:459-70. https://doi.org/10.1161/01.RES.0000141146.95728.da.

[4] Yacoub MH, Cohn LH. Novel Approaches to Cardiac Valve Repair. From Structure to Function: Part I. Circulation 2004;109:1064-1072. https://doi.org/10.1161/01.CIR.0000115633.19829.5E.

[5] Roy A, Brand NJ, Yacoub MH. Molecular characterization of interstitial cells isolated from human heart valves. J Heart Valve Dis 2000;9:459-64.

[6] Yacoub MH, Takkenberg JJM. Will heart valve tissue engineering change the world? Nat Clin Pract Cardiovasc Med 2005;2:60-1. https://doi.org/10.1038/ncpcardio0112.

[7] Kalozoumi G, Tzimas C, Sanoudou D. The expanding role of epigenetics. Glob Cardiol Sci Pract 2012;2012:7. https://doi.org/10.5339/gcsp.2012.7.

[8] Miller JL, Grant PA. The role of DNA methylation and histone modifications in transcriptional regulation in humans. Subcell Biochem 2013;61:289-317. https://doi.org/10.1007/978-94-0074525-4_13.

[9] Gilsbach R, Preissl S, Grüning BA, Schnick T, Burger L, Benes V, et al. Dynamic DNA methylation orchestrates cardiomyocyte development, maturation and disease. Nat Commun 2014;5:5288. https://doi.org/10.1038/ncomms6288.

[10] Chaturvedi P, Tyagi SC. Epigenetic mechanisms underlying cardiac degeneration and regeneration. Int J Cardiol 2014;173:1-11. https://doi.org/10.1016/j.ijcard.2014.02.008.

[11] Zhu C, Yu Z Bin, Chen XH, Pan Y, Dong XY, Qian LM, et al. Screening for differential methylation status in fetal myocardial tissue samples with ventricular septal defects by promoter methylation microarrays. Mol Med Rep 2011;4:137-43. https://doi.org/10.3892/mmr.2010.407.

[12] Sheng W, Qian Y, Zhang P, Wu Y, Wang H, Ma X, et al. Association of promoter methylation statuses of congenital heart defect candidate genes with tetralogy of fallot. J Transl Med 2014;12. https://doi.org/10.1186/1479-5876-12-31.

[13] Tabaei S, Tabaee SS. DNA methylation abnormalities in atherosclerosis. Artif Cells, Nanomedicine, Biotechnol 2019;47:2031-41. https://doi.org/10.1080/21691401.2019.1617724.

[14] Movassagh M, Choy MK, Knowles DA, Cordeddu L, Haider S, Down T, et al. Distinct epigenomic features in end-stage failing human hearts. Circulation 2011;124:2411-22. https://doi.org/10.1161/CIRCULATIONAHA.111.040071.

[15] Nagy E, Bäck M. Epigenetic regulation of 5-lipoxygenase in the phenotypic plasticity of valvular interstitial cells associated with aortic valve stenosis. FEBS Lett 2012;586:1325-9. https://doi.org/10.1016/j.febslet.2012.03.039.

[16] Haunschild J, Schellinger I, Barnard S, von Aspern K, Davierwala P, Misfeld M, et al. Bicuspid Aortic Valve Patients Show Specific Epigenetic Tissue Signature Increasing Extracellular Matrix Destruction. Interact Cardiovasc Thorac Surg 2019;29:937-43. https://doi.org/10.1093/ICVTS/IVZ210.

[17] Shen K, Liu H, Jing R, Yi J, Zhou X. DNA methylation dysregulations in rheumatic heart valve disease. BMC Cardiovasc Disord 2017;17:159. https://doi.org/10.1186/s12872-017-0585-3.

[18] Pan S, Lai H, Shen Y, Breeze C, Beck S, Hong T, et al. DNA methylome analysis reveals distinct epigenetic patterns of ascending aortic dissection and bicuspid aortic valve. Cardiovasc Res 2017;113:692-704. https://doi.org/10.1093/cvr/cvx050. 
It is made available under a CC-BY-NC-ND 4.0 International license .

[19] Latif N, Sarathchandra P, Chester AH, Yacoub MH. Expression of smooth muscle cell markers and co-activators in calcified aortic valves. Eur Heart J 2015;36:1335-45. https://doi.org/10.1093/eurheartj/eht547.

[20] Andrews S. FastQC A Quality Control tool for High Throughput Sequence Data. 2010. https://www.bioinformatics.babraham.ac.uk/projects/fastqc/.

[21] Krueger F. Trim Galore. A wrapper tool around Cutadapt and FastQC to consistently apply quality and adapter trimming to FastQ files. 2015.

https://www.bioinformatics.babraham.ac.uk/projects/trim_galore/.

[22] Krueger F, Andrews S. Bismark: a flexible aligner and methylation caller for Bisulfite-Seq applications. Bioinformatics 2011;27:1571-2. https://doi.org/10.1093/bioinformatics/btr167.

[23] Langmead B, Trapnell C, Pop M, Salzberg SL. Ultrafast and memory-efficient alignment of short DNA sequences to the human genome. Genome Biol 2009;10:R25. https://doi.org/10.1186/gb2009-10-3-r25.

[24] Li H, Handsaker B, Wysoker A, Fennell T, Ruan J, Homer N, et al. The Sequence Alignment/Map Format and SAMtools. Bioinformatics 2009;25:2078-9. https://doi.org/10.1093/bioinformatics/btp352.

[25] Akalin A, Kormaksson M, Li S, Garrett-Bakelman FE, Figueroa ME, Melnick A, et al. methylKit: a comprehensive R package for the analysis of genome-wide DNA methylation profiles. Genome Biol 2012;13:R87. https://doi.org/10.1186/gb-2012-13-10-R87.

[26] Karolchik D, Hinrichs A, Furey T, Roskin K, Sugnet C, Haussler D, et al. The UCSC Table Browser Data Retrieval Tool. Nucleic Acids Res 2004;32:D493-6.

[27] Mi H, Muruganujan A, Casagrande JT, Thomas PD. Large-scale gene function analysis with the panther classification system. Nat Protoc 2013;8:1551-66. https://doi.org/10.1038/nprot.2013.092.

[28] Xia J, Benner M, Hancock R. NetworkAnalyst - integrative approaches for protein-protein interaction network analysis and visual exploration. Nucleic Acids Res 2014;42:W167-74. https://doi.org/10.1093/nar/gku443.

[29] Walter W, Sánchez-Cabo F, Ricote M. GOplot: An R Package for Visually Combining Expression Data With Functional Analysis. Bioinformatics 2015;31:2912-4. https://doi.org/10.1093/bioinformatics/btv300.

[30] Combs MD, Yutzey KE. Heart valve development: Regulatory networks in development and disease. Circ Res 2009;105:408-21. https://doi.org/10.1161/CIRCRESAHA.109.201566.

[31] Anderson R, Ho SY, Becker AE. Anatomy of the human atrioventricular junctions revisited. Anat Rec 2000;260:81-91. https://doi.org/10.1002/1097-0185(20000901)260:1<81::AIDAR90>3.0.CO;2-3.

[32] Zimmerman J. The functional and surgical anatomy of the heart. Ann R Coll Surg Engl 1966;39:348-66.

[33] Yacoub MH, Kilner PJ, Birks EJ, Misfeld M. The aortic outflow and root: A tale of dynamism and crosstalk. Ann Thorac Surg 1999;68:S37-43. https://doi.org/10.1016/s0003-4975(99)00745-6.

[34] Tsakiris AG, Von Bernuth G, Rastelli GC, Bourgeois MJ, Titus JL, Wood EH. Size and motion of the mitral valve annulus in anesthetized intact dogs. J Appl Physiol 1971;30:611-8. https://doi.org/10.1152/jappl.1971.30.5.611.

[35] Rapaport E. Natural history of aortic and mitral valve disease. Am J Cardiol 1975;35:221-7. https://doi.org/10.1016/0002-9149(75)90005-3.

[36] Lee YK, Jin S, Duan S, Lim YC, Ng DP, Lin XM, et al. Improved reduced representation bisulfite 
It is made available under a CC-BY-NC-ND 4.0 International license .

sequencing for epigenomic profiling of clinical samples. Biol Proced Online 2014;16:1. https://doi.org/10.1186/1480-9222-16-1.

[37] Gu H, Smith ZD, Bock C, Boyle P, Gnirke A, Meissner A. Preparation of reduced representation bisulfite sequencing libraries for genome-scale DNA methylation profiling. Nat Protoc 2011;6:468-81. https://doi.org/10.1038/nprot.2010.190.

[38] Carmona JJ, Accomando WP, Binder AM, Hutchinson JN, Pantano L, Izzi B, et al. Empirical comparison of reduced representation bisulfite sequencing and Infinium BeadChip reproducibility and coverage of DNA methylation in humans. Npj Genomic Med 2017;2:13. https://doi.org/10.1038/s41525-017-0012-9.

[39] Shi ST, De Gorter DJJ, Hoogaars WMH, Hoen PAC, Ten Dijke P. Overactive bone morphogenetic protein signaling in heterotopic ossification and Duchenne muscular dystrophy. Cell Mol Life Sci 2013;70:407-23. https://doi.org/10.1007/s00018-012-1054-x.

[40] Gomez-Stallons MV, Wirrig-Schwendeman EE, Hassel KR, Conway SJ, Yutzey KE. Bone Morphogenetic Protein Signaling Is Required for Aortic Valve Calcification. Arterioscler Thromb Vasc Biol 2016;36:1398-405. https://doi.org/10.1161/ATVBAHA.116.307526.

[41] Adly N, Alhashem A, Ammari A, Alkuraya FS. Ciliary Genes TBC1D32/C6orf170 and SCLT1 are Mutated in Patients with OFD Type IX. Hum Mutat 2014;35:36-40. https://doi.org/10.1002/humu.22477.

[42] Pierpont ME, Brueckner M, Chung WK, Garg V, Lacro R V., McGuire AL, et al. Genetic Basis for Congenital Heart Disease: Revisited: A Scientific Statement from the American Heart Association. Circulation 2018;138:e653-711. https://doi.org/10.1161/CIR.0000000000000606.

[43] Toomer KA, Fulmer D, Guo L, Drohan A, Peterson N, Swanson P, et al. A role for primary cilia in aortic valve development and disease. Dev Dyn 2017;246:625-34. https://doi.org/10.1002/dvdy.24524.

[44] Marchetti G, Girelli D, Zerbinati C, Lunghi B, Friso S, Meneghetti S, et al. An integrated genomic-transcriptomic approach supports a role for the proto-oncogene BCL3 in atherosclerosis. Thromb Haemost 2015;113:655-63. https://doi.org/10.1160/TH14-05-0466.

[45] Kuusisto J, Räsänen K, Särkioja T, Alarakkola E, Kosma VM. Atherosclerosis-like lesions of the aortic valve are common in adults of all ages: A necropsy study. Heart 2005;91:576-82. https://doi.org/10.1136/hrt.2004.036848.

[46] Liu Y. Role Of Nitric Oxide In Embryonic Heart Development And Adult Aortic Valve Disease. The University of Western Ontario, 2014.

[47] Matsson H, Eason J, Bookwalter CS, Klar J, Gustavsson P, Sunnegårdh J, et al. Alpha-cardiac actin mutations produce atrial septal defects. Hum Mol Genet 2008;17:256-65. https://doi.org/10.1093/hmg/ddm302.

[48] England J, Loughna S. Heavy and light roles: Myosin in the morphogenesis of the heart. Cell Mol Life Sci 2013;70:1221-39. https://doi.org/10.1007/s00018-012-1131-1.

[49] Hulin A, Deroanne C, Lambert C, Defraigne JO, Nusgens B, Radermecker M, et al. Emerging pathogenic mechanisms in human myxomatous mitral valve: Lessons from past and novel data. Cardiovasc Pathol 2013;22:245-50. https://doi.org/10.1016/j.carpath.2012.11.001.

[50] Hulin A, Deroanne CF, Lambert CA, Dumont B, Castronovo V, Defraigne J-O, et al. Metallothionein-dependent Up-Regulation of TGF- $\beta 2$ Participates in the Remodelling of the Myxomatous Mitral Valve. Cardiovasc Res 2012;93:480-9. https://doi.org/10.1093/cvr/cvr337.

[51] Thalji NM, Hagler MA, Zhang H, Casaclang-Verzosa G, Nair AA, Suri RM, et al. Nonbiased 
It is made available under a CC-BY-NC-ND 4.0 International license .

Molecular Screening Identifies Novel Molecular Regulators of Fibrogenic and Proliferative Signaling in Myxomatous Mitral Valve Disease. Circ Cardiovasc Genet 2015;8:516-28. https://doi.org/10.1161/CIRCGENETICS.114.000921.

[52] Blunder S, Messner B, Scharinger B, Doppler C, Zeller I, Zierer A, et al. Targeted gene expression analyses and immunohistology suggest a pro-proliferative state in tricuspid aortic valve-, and senescence and viral infections in bicuspid aortic valve-associated thoracic aortic aneurysms. Atherosclerosis 2018;271:111-9. https://doi.org/10.1016/j.atherosclerosis.2018.02.007.

[53] Padang R, Bagnall RD, Tsoutsman T, Bannon PG, Semsarian C. Comparative transcriptome profiling in human bicuspid aortic valve disease using RNA sequencing. Physiol Genomics 2015;47:75-87. https://doi.org/10.1152/physiolgenomics.00115.2014.

[54] Grassini DR, Lagendijk AK, De Angelis JE, Da Silva J, Jeanes A, Zettler N, et al. Nppa and nppb act redundantly during zebrafish cardiac development to confine AVC marker expression and reduce cardiac jelly volume. Dev 2018;145. https://doi.org/10.1242/dev.160739.

[55] Sergeeva IA, Christoffels VM. Regulation of expression of atrial and brain natriuretic peptide, biomarkers for heart development and disease. Biochim Biophys Acta - Mol Basis Dis 2013;1832:2403-13. https://doi.org/10.1016/j.bbadis.2013.07.003.

[56] Chamberlain AA, Lin M, Lister RL, Maslov AA, Wang Y, Suzuki M, et al. DNA methylation is developmentally regulated for genes essential for cardiogenesis. J Am Heart Assoc 2014;3:e000976. https://doi.org/10.1161/JAHA.114.000976.

[57] Grande-Allen KJ, Osman N, Ballinger ML, Dadlani H, Marasco S, Little PJ. Glycosaminoglycan synthesis and structure as targets for the prevention of calcific aortic valve disease. Cardiovasc Res 2007;76:19-28. https://doi.org/10.1016/j.cardiores.2007.05.014.

[58] Albanese I, Yu B, Al-Kindi H, Barratt B, Ott L, Al-Refai M, et al. Role of Noncanonical Wnt Signaling Pathway in Human Aortic Valve Calcification. Arterioscler Thromb Vasc Biol 2017;37:543-52. https://doi.org/10.1161/ATVBAHA.116.308394.

[59] Bossé Y, Miqdad A, Fournier D, Pépin A, Pibarot P, Mathieu P. Refining Molecular Pathways Leading to Calcific Aortic Valve Stenosis by Studying Gene Expression Profile of Normal and Calcified Stenotic Human Aortic Valves. Circ Cardiovasc Genet 2009;2:489-98. https://doi.org/10.1161/CIRCGENETICS.108.820795.

[60] Mohamed SA, Hanke T, Schlueter C, Bullerdiek J, Sievers HH. Ubiquitin fusion degradation 1like gene dysregulation in bicuspid aortic valve. J Thorac Cardiovasc Surg 2005;130:1531-6. https://doi.org/10.1016/j.jtcvs.2005.08.017.

[61] Yamada T, Satoh S, Sueyoshi S, Mitsumata M, Matsumoto T, Ueno T, et al. Ubiquitin-Positive Foam Cells are Identified in the Aortic and Mitral Valves with Atherosclerotic Involvement. J Atheroscler Thromb 2009;16:472-9. https://doi.org/10.5551/jat.No1248.

[62] Day SM. The ubiquitin proteasome system in human cardiomyopathies and heart failure. Am J Physiol - Hear Circ Physiol 2013;304:H1283-93. https://doi.org/10.1152/ajpheart.00249.2012.

[63] Li F-F, Zhou J, Zhao D-D, Yan P, Li X, Han Y, et al. Characterization of SMAD3 Gene Variants for Possible Roles in Ventricular Septal Defects and Other Congenital Heart Diseases. PLoS One 2015;10:e0131542. https://doi.org/10.1371/journal.pone.0131542.

[64] Regalado ES, Guo DC, Villamizar C, Avidan N, Gilchrist D, McGillivray B, et al. Exome sequencing identifies SMAD3 mutations as a cause of familial thoracic aortic aneurysm and dissection with intracranial and other arterial aneurysms. Circ Res 2011;109:680-6. https://doi.org/10.1161/CIRCRESAHA.111.248161. 
It is made available under a CC-BY-NC-ND 4.0 International license .

[65] Kubalak SW, Hutson DR, Scott KK, Shannon RA. Elevated transforming growth factor beta2 enhances apoptosis and contributes to abnormal outflow tract and aortic sac development in retinoic X receptor alpha knockout embryos. Development 2002;129:733-46.

[66] Zhang Y, Ma L. Identification of key genes and pathways in calcific aortic valve disease by bioinformatics analysis. J Thorac Dis 2019;11:5417-26. https://doi.org/10.21037/jtd.2019.11.57.

[67] Radhakrishna U, Albayrak S, Alpay-Savasan Z, Zeb A, Turkoglu O, Sobolewski P, et al. Genomewide DNA methylation analysis and epigenetic variations associated with Congenital Aortic Valve Stenosis (AVS). PLoS One 2016;11. https://doi.org/10.1371/journal.pone.0154010.

[68] Thanassoulis G. Preventing Aortic Stenosis by Changing the Way We Think about an Old Disease. JAMA Cardiol 2020;5:627-9. https://doi.org/10.1001/jamacardio.2020.0722.

[69] Bergmark BA, O’Donoghue ML, Murphy SA, Kuder JF, Ezhov M V., Češka R, et al. An Exploratory Analysis of Proprotein Convertase Subtilisin/Kexin Type 9 Inhibition and Aortic Stenosis in the FOURIER Trial. JAMA Cardiol 2020;5:709-13. https://doi.org/10.1001/jamacardio.2020.0728.

[70] Macgrogan D, Luna-Zurita L, de la Pompa JL. Notch signaling in cardiac valve development and disease. Birth Defects Res Part A - Clin Mol Teratol 2011;91:449-59. https://doi.org/10.1002/bdra.20815.

[71] Walker GA, Masters KS, Shah DN, Anseth KS, Leinwand LA. Valvular myofibroblast activation by transforming growth factor- $\beta$ : Implications for pathological extracellular matrix remodeling in heart valve disease. Circ Res 2004;95:253-60. https://doi.org/10.1161/01.RES.0000136520.07995.aa.

[72] Ng CM, Cheng A, Myers LA, Martinez-Murillo F, Jie C, Bedja D, et al. TGF- $\beta$-dependent pathogenesis of mitral valve prolapse in a mouse model of Marfan syndrome. J Clin Invest 2004;114:1586-92. https://doi.org/10.1172/JCI22715.

[73] Clark-Greuel JN, Connolly JM, Sorichillo E, Narula NR, Rapoport HS, Mohler Iii ER, et al. Transforming Growth Factor-1 Mechanisms in Aortic Valve Calcification: Increased Alkaline Phosphatase and Related Events. Ann 2007;83:946-53. https://doi.org/10.1016/j.athoracsur.2006.10.026.

[74] Zhang J, Chang JYF, Huang Y, Lin X, Luo Y, Schwartz RJ, et al. The FGF-BMP signaling axis regulates outflow tract valve primordium formation by promoting cushion neural crest cell differentiation. Circ Res 2010;107:1209-19. https://doi.org/10.1161/CIRCRESAHA.110.225318.

[75] Zhou J, Bowen C, Lu G, Knapp C, Recknagel A, Norris RA, et al. Cadherin-11 expression patterns in heart valves associate with key functions during embryonic cushion formation, valve maturation and calcification. Cells Tissues Organs 2013;198:300-10. https://doi.org/10.1159/000356762.

[76] Bloomekatz J, Singh R, Prall OWJ, Dunn AC, Vaughan M, Loo CS, et al. Platelet-derived growth factor (PDGF) signaling directs cardiomyocyte movement toward the midline during heart tube assembly. Elife 2017;6. https://doi.org/10.7554/eLife.21172.

[77] Li R, Wu Y, Manso AM, Gu Y, Liao P, Israeli S, et al. $\beta 1$ integrin gene excision in the adult murine cardiac myocyte causes defective mechanical and signaling responses. Am J Pathol 2012;180:952-62. https://doi.org/10.1016/j.ajpath.2011.12.007.

[78] Kamel PI, Qu X, Geiszler AM, Nagrath D, Harmancey R, Taegtmeyer H, et al. Metabolic regulation of collagen gel contraction by porcine aortic valvular interstitial cells. J R Soc Interface 2014;11:20140852. https://doi.org/10.1098/rsif.2014.0852. 
It is made available under a CC-BY-NC-ND 4.0 International license .

[79] Salhiyyah K, Sarathchandra P, Latif N, Yacoub MH, Chester AH. Hypoxia-mediated regulation of the secretory properties of mitral valve interstitial cells. Am J Physiol Circ Physiol 2017;313:H1423. https://doi.org/10.1152/ajpheart.00720.2016.

[80] Yoshioka M, Yuasa S, Matsumura K, Kimura K, Shiomi T, Kimura N, et al. Chondromodulin-I maintains cardiac valvular function by preventing angiogenesis. Nat Med 2006;12:1151-9. https://doi.org/10.1038/nm1476.

[81] Yeh CY, Shun CT, Kuo YM, Jung CJ, Hsieh SC, Chiu YL, et al. Activated human valvular interstitial cells sustain interleukin-17 production to recruit neutrophils in infective endocarditis. Infect Immun 2015;83:2202-12. https://doi.org/10.1128/IAI.02965-14.

[82] Akahori H, Tsujino T, Naito Y, Sawada H, Sugahara M, Fukui M, et al. Nuclear factor-kBhypoxia-inducible factor-2 Pathway in Aortic Valve Stenosis. J Heart Valve Dis 2014;23:558-66.

[83] Yu Z, Seya K, Daitoku K, Motomura S, Fukuda I, Furukawa KI. Tumor necrosis factor- $\alpha$ accelerates the calcification of human aortic valve interstitial cells obtained from patients with calcific aortic valve stenosis via the BMP2-Dlx5 pathway. J Pharmacol Exp Ther 2011;337:16-23. https://doi.org/10.1124/jpet.110.177915.

[84] Nagy E, Eriksson P, Yousry M, Caidahl K, Ingelsson E, Hansson GK, et al. Valvular osteoclasts in calcification and aortic valve stenosis severity. Int J Cardiol 2013;168:2264-71. https://doi.org/10.1016/j.ijcard.2013.01.207.

[85] Peltonen T, Taskinen P, Näpänkangas J, Leskinen H, Ohtonen P, Soini Y, et al. Increase in Tissue endothelin-1 and ETA Receptor Levels in Human Aortic Valve Stenosis. Eur Heart J 2009;30:242-9. https://doi.org/https://doi-org.eres.qnl.qa/10.1093/eurheartj/ehn482.

[86] Jian B, Narula N, Li QY, Mohler ER, Levy RJ. Progression of aortic valve stenosis: TGF- $\beta 1$ is present in calcified aortic valve cusps and promotes aortic valve interstitial cell calcification via apoptosis. Ann Thorac Surg 2003;75:457-65. https://doi.org/10.1016/S0003-4975(02)04312-6.

[87] Mebazaa A, Mayoux E, Maeda K, Martin LD, Lakatta EG, Robotham JL, et al. Paracrine effects of endocardial endothelial cells on myocyte contraction mediated via endothelin. Am J Physiol Hear Circ Physiol 1993;265:H1841-6. https://doi.org/10.1152/ajpheart.1993.265.5.h1841.

[88] Lee W-S, Kim J. Peroxisome Proliferator-Activated Receptors and the Heart: Lessons from the Past and Future Directions. PPAR Res 2015;2015:18 pages. https://doi.org/10.1155/2015/271983.

[89] Goyal G, Abbas SH, Diamond MA, Pulinthanathu R. Fatty Infiltration of Mitral Valve: A Rare Case Report and Review of Literature. Cureus 2019;11:e6144. https://doi.org/10.7759/cureus.6144. 